\title{
Theoretical Determination of the Properties of Methanesulfinic and Methanesulfonic Acids
}

\author{
Nathália F. Carvalho, Simão P. Silva and Stella M. Resende* \\ Departamento de Ciências Naturais, Universidade Federal de São João del Rei, \\ 36301-160 São João del Rei-MG, Brazil
}

\begin{abstract}
As propriedades estruturais, espectroscópicas e termodinâmicas de duas espécies de enxofre de interesse atmosférico, ácidos metanosulfínico $\left(\mathrm{CH}_{3} \mathrm{~S}(\mathrm{O}) \mathrm{OH}\right.$, MSIA) e metanosulfônico $\left(\mathrm{CH}_{3} \mathrm{~S}(\mathrm{O})_{2} \mathrm{OH}, \mathrm{MSA}\right)$ foram determinadas no nível de $\mathrm{CCSD}(\mathrm{T}) / \mathrm{CBS}$ (coupled-cluster with single and double and perturbative triple excitations/complete basis set) de teoria. Duas conformações foram encontradas para o ácido metanosulfínico e o valor médio determinado para a entalpia de formação foi $-337,2 \mathrm{~kJ} \mathrm{~mol}^{-1}$. Para o ácido metanosulfônico, o resultado para a entalpia de formação foi $566,2 \mathrm{~kJ} \mathrm{~mol}^{-1}$. Escolhendo cuidadosamente as reações químicas e considerando a existência de duas conformações de MSIA, esta investigação reporta os valores mais precisos de $\Delta \mathrm{H}_{\mathrm{f}}$ disponíveis até agora para estas espécies.
\end{abstract}

The structural, spectroscopic and thermochemical properties of two sulfur species of atmospheric interest, methanesulfinic $\left(\mathrm{CH}_{3} \mathrm{~S}(\mathrm{O}) \mathrm{OH}\right.$, MSIA) and methanesulfonic $\left(\mathrm{CH}_{3} \mathrm{~S}(\mathrm{O})_{2} \mathrm{OH}\right.$, MSA) acids, were determined at the $\mathrm{CCSD}(\mathrm{T}) / \mathrm{CBS}$ (coupled-cluster with single and double and perturbative triple excitations/complete basis set) level of theory. Two stable conformers were found to the methanesulfinic acid, and the determined average value for the enthalpy of formation $\left(\Delta \mathrm{H}_{\mathrm{f}}\right)$ was $-337.2 \mathrm{~kJ} \mathrm{~mol}^{-1}$. For methanesulfonic acid, the determined enthalpy of formation was $566.2 \mathrm{~kJ} \mathrm{~mol}^{-1}$. By carefully choosing of the chemical reactions and considering the existence of two MSIA conformers, this investigation reports the most accurate $\Delta \mathrm{H}_{\mathrm{f}}$ values available to date for these species.

Keywords: dimethyl sulfide, enthalpy of formation, CCSD(T)/CBS theory

\section{Introduction}

Dimethyl sulfide (DMS), generated in the ocean by phytoplankton, is an important natural source of sulfur in the atmosphere. ${ }^{1}$ The main final products of its atmospheric decomposition are sulfuric acid and sulfate ions, which are key species in the climate regulation, due to the fact that they are precursors of aerosols. Sulfur aerosols act in the global warming producing a negative radiative forcing, dispersing the solar radiation and increasing the albedo. ${ }^{2}$ Besides, due to the low gas pressure and polarity, these species can act as cloud condensation nuclei $(\mathrm{CCN})$, condensing water molecules. ${ }^{3,4}$

Several experimental and theoretical investigations of the oxidation of DMS in gas phase were conducted ${ }^{5-7}$ and studies for $\mathrm{OH}$-initiated reaction had revealed methanesulfonic acid $\left(\mathrm{CH}_{3} \mathrm{~S}(\mathrm{O})_{2} \mathrm{OH}, \mathrm{MSA}\right)^{8}$ and methanesulfinic acid $\left(\mathrm{CH}_{3} \mathrm{~S}(\mathrm{O})\right.$

*e-mail: stella@ufsj.edu.br
OH, MSIA $)^{9}$ as two key intermediates. In general, there are some difficulties in the characterization of the products, and the values of product yields reported can differ significantly. It is generally accepted that MSA is produced from the $\mathrm{OH}$ addition to DMS, in a mechanism highly dependent on temperature and $\mathrm{O}_{2}$ partial pressure. On the other hand, the presence of MSIA in the atmospheric decomposition of DMS was proposed by Yin et al. ${ }^{10}$ as a second-generation product of the DMS oxidation. However, the mechanism and the yields of MSIA formation were reasons of great discussions in the literature. ${ }^{9,11,12}$

Although the processes of the formation of MSA and MSIA in the atmosphere are reasonably well established today, their complete atmospheric decomposition was not elucidated yet, except by reaction with $\cdot \mathrm{OH}$ radicals. ${ }^{13,14}$ Also, data about their properties are scarce in the literature. Guthrie and Gallant ${ }^{15}$ have determined the enthalpy of formation of MSA through an experimental study of the reaction between the sulfide ion and metil-methanesulfonate 
in aqueous solution, where MSA is one of the products. There are not experimental results about the thermochemical and spectroscopic properties of MSIA. Wang and Zhang ${ }^{16}$ have determined theoretically the enthalpy of formation of the MSA and MSIA using the G3 theory (Gaussian-3 method) with MP2/cc-pVTZ and B3LYP/6-31G(d) levels (optimized geometries) of theory for the optimizations. However, it is a consensus that molecules with second row atoms as sulfur need to be investigated with basis sets that treats the dissociation more accurately, ${ }^{17}$ and today it is possible to include the electronic correlation in a more precise way. In this context, these theoretical calculations may not be accurate. Besides, it is important to characterize accurately these two important atmospheric species in their structural, spectroscopic and thermodynamical aspects. So, our aim in this work is to conduct an extensive characterization of these species using more confident $a b$ initio methods.

\section{Methodology}

All calculations were conducted with the Gaussian 03 package of programs. ${ }^{18}$ The optimization of the stationary points and the harmonic frequencies calculations were performed at the UMP2/cc-pV(T+d)Z level of calculation. The tight d-augmented correlation consistent basis sets, ${ }^{19} \mathrm{cc}-\mathrm{pV}(\mathrm{n}+\mathrm{d}) \mathrm{Z}$, were developed to correct errors found in extrapolating dissociation energies calculated with the standard correlation consistent basis sets (cc-pVnZ) to the complete basis set limit for molecules containing second row atoms. Single point calculations with the cc-pV(D+d)Z and cc-pV $(Q+d) Z$ basis set, at the UMP2 level were done at the optimized $\mathrm{UMP} 2 / \mathrm{cc}-\mathrm{pV}(\mathrm{T}+\mathrm{d}) \mathrm{Z}$ geometry in order to obtain the complete basis set limit (CBS), according the approximation of Dunning et al. ${ }^{19}$ The best level of electronic correlation was achieved through the additivity approximation, ${ }^{20,21}$ using a single point calculation at the $\operatorname{CCSD}(\mathrm{T}) / \mathrm{cc}-\mathrm{pV}(\mathrm{T}+\mathrm{d}) \mathrm{Z}$ level of theory. In this way, our best level of calculation for the electronic energy is CCSD(T)/CBS.

The enthalpy and Gibbs free energy for all species considered in this work were determined through the statistical thermodynamics, considering the vibrational, rotational and translational modes determined to the optimized geometries. The values for $\Delta \mathrm{H}$ and $\Delta \mathrm{G}$ were calculated, respectively, by the differences among enthalpies and Gibbs free energies for products and reactants.

\section{Results and Discussion}

Initially, a detailed conformation analysis was done for the two species in this study. For MSA, there is only one stable conformation, which is represented in Figure 1. In this species, there are two $\mathrm{S}=\mathrm{O}$ double bonds and one $\mathrm{S}-\mathrm{O}$ single bond. On the other hand, MSIA has two stable conformers that differ in the position of the hydrogen bond to the oxygen. The most stable conformer (MSIA1) has a HOSC dihedral angle equal to $169^{\circ}$, while in the other conformer (MSIA2), this dihedral angle amounts to $-69^{\circ}$. These two species are also depicted in the Figure 1, along with the main geometrical parameters. MSIA1 is more stable than MSIA2 by $3.2 \mathrm{~kJ} \mathrm{~mol}^{-1}$. Two transition states were found connecting these two conformers, with dihedral angles of $31^{\circ}$ and $-127^{\circ}$, respectively, identified here by MSIA-TS1 and MSIA-TS2, which are also depicted in Figure 1. The imaginary frequencies of MSIA-TS1 and MSIA-TS2 are 304,9i and 333,9i, respectively.

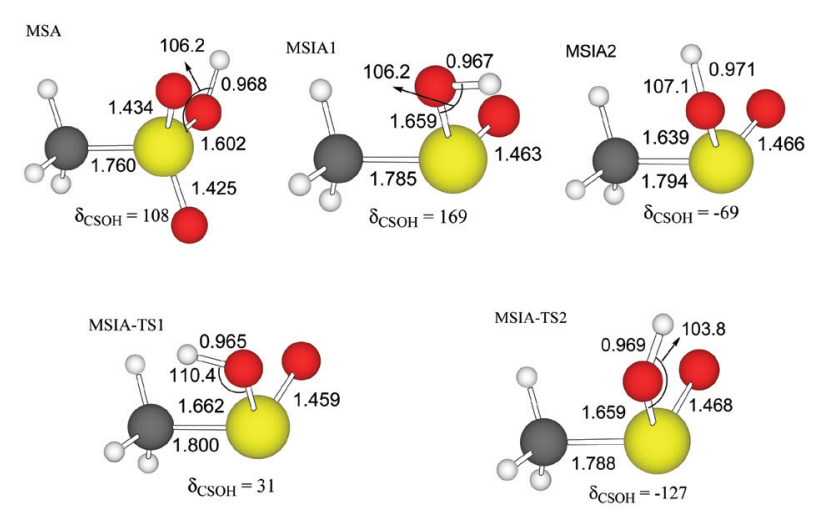

Figure 1. Structural representations of the MSA, MSA1, MSA2 and the transition states MSIA-TS1 and MSIA-TS2 obtained at the $\mathrm{UMP} 2 / \mathrm{cc}-\mathrm{pV}(\mathrm{T}+\mathrm{d}) \mathrm{Z}$ level of theory.

The electronic energy barriers for interconvertion were calculated to be 7.5 and $23.8 \mathrm{~kJ} \mathrm{~mol}^{-1}$, in relation to MSIA-TS1 and MSIA-TS2, respectively, which indicate that this rotation is almost barrierless. The reaction free energy to interconvertion of MSIA1 into MSIA2 was determined to be $2.13 \mathrm{~kJ} \mathrm{~mol}^{-1}$, and this value was used to calculate the distribution of these two conformers at the equilibrium, using the following equation:

$\frac{\mathrm{N} 2}{\mathrm{~N} 1}=\mathrm{e}^{-\Delta \mathrm{G}_{21} / \mathrm{RT}}$

where $\mathrm{N}_{1}$ and $\mathrm{N}_{2}$ are the amount of MSIA1 and MSIA2 conformers, respectively; and $\Delta \mathrm{G}_{21}$ is the reaction free energy for MSIA1 $\rightarrow$ MSIA2 interconversion. The proportion of each conformer in the equilibrium was determined to be $70 \%$ to MSIA1 and $30 \%$ to MSIA2, and the equilibrium constant to MSIA1 to MSIA2 interconversion was calculated to be 0.43 .

The calculated harmonic frequencies of MSA, MSIA1 and MSIA2 are listed in Table 1, along with the experimental 
Table 1. Harmonic vibrational frequencies $\left(\mathrm{cm}^{-1}\right)$ calculated and experimenta ${ }^{22}$ for MSA and for the two MSIA conformers (MSIA1 and MSIA2), calculated at the UMP2/cc-pV(T+d)Z level of theory

\begin{tabular}{|c|c|c|c|c|c|}
\hline Mode & $\operatorname{MSA}\left(\mathrm{cm}^{-1}\right)$ & $\operatorname{MSA}_{\exp }{ }^{22}\left(\mathrm{~cm}^{-1}\right)$ & Mode & $\operatorname{MSIA1}\left(\mathrm{cm}^{-1}\right)$ & $\operatorname{MSIA} 2\left(\mathrm{~cm}^{-1}\right)$ \\
\hline $\mathrm{OH}$ torsion & 211 & & $\mathrm{CH}_{3}$ torsion & 210 & 231 \\
\hline $\mathrm{CH}_{3}$ torsion & 236 & & $\mathrm{OH}$ torsion & 299 & 254 \\
\hline CSO bending & 318 & $326.0^{23}$ & & 344 & 320 \\
\hline $\mathrm{SO}_{2}$ twist & 340 & $336.0^{23}$ & & 365 & 411 \\
\hline $\mathrm{SO}_{2}$ rock & 449 & 454.4 & $\mathrm{OH}$ torsion & 457 & 457 \\
\hline $\mathrm{SO}_{2}$ wag & 502 & 496.8 & C-S stretching & 724 & 707 \\
\hline $\mathrm{SO}_{2}$ bending & 535 & 526.9 & S-OH stretching & 743 & 769 \\
\hline CS stretching & 771 & 746.5 & & 952 & 942 \\
\hline SO stretching & 854 & 832.5 & & 957 & 949 \\
\hline $\mathrm{CH}_{3}$ rock & 981 & 967.0 & HOS bending & 1175 & 1137 \\
\hline $\mathrm{CH}_{3}$ rock & 993 & 975.3 & $\mathrm{~S}=\mathrm{O}$ stretching & 1240 & 1240 \\
\hline SOH bending & 1143 & 1118.3 & $\mathrm{CH}_{3}$ bending & 1332 & 1329 \\
\hline $\mathrm{SO}_{2}$ symmetric stretching & 1238 & 1193.6 & $\mathrm{CH}_{3}$ bending & 1464 & 1459 \\
\hline $\mathrm{CH}_{3}$ symmetric stretching & 1364 & 1332.8 & $\mathrm{CH}_{3}$ bending & 1469 & 1473 \\
\hline $\mathrm{SO}_{2}$ anti-symmetric stretching & 1456 & 1393.4 & $\mathrm{CH}_{3}$ symmetric stretching & 3087 & 3074 \\
\hline $\mathrm{CH}_{3}$ anti-symmetric bending & 1473 & 1422.1 & $\mathrm{CH}_{3}$ symmetric stretching & 3206 & 3188 \\
\hline $\mathrm{CH}_{3}$ anti-symmetric bending & 1483 & 1434.0 & $\mathrm{CH}_{3}$ anti-symmetric stretching & 3214 & 3206 \\
\hline $\mathrm{CH}_{3}$ symmetric stretching & 3105 & 3047.0 & $\mathrm{OH}$ stretching & 3804 & 3728 \\
\hline $\mathrm{CH}_{3}$ anti-symmetric stretching & 3218 & 3188.5 & & & \\
\hline $\mathrm{CH}_{3}$ anti-symmetric stretching & 3228 & 3204.5 & & & \\
\hline OH stretching & 3802 & 3579.4 & & & \\
\hline
\end{tabular}

values available in the literature for MSA..$^{22,23}$ The present values are in very good agreement with the experimental results, with a average error of $2 \%$. For MSIA, there are not experimental results in the literature. From these data, there are spectroscopic differences between the two MSIA conformers. The $\mathrm{OH}, \mathrm{S}-\mathrm{OH}$ and $\mathrm{S}=\mathrm{O}$ stretching modes, and the HOS bending mode are the main frequencies of MSIA1, while in MSIA2 the intensity of the $\mathrm{S}=\mathrm{O}$ stretching and the HOS bending is very small. This can be used to identify the conformers in experimental measurements.

After the structural and spectroscopic characterization of these two species, the calculations of the thermodynamical properties were done. For the determination of the enthalpy of formation $\left(\Delta \mathrm{H}_{\mathrm{f}}^{\circ}\right)$ of these compounds, three isodesmic reactions were used:

$$
\begin{aligned}
& \mathrm{CH}_{3} \mathrm{~S}(\mathrm{O}) \mathrm{CH}_{3}+\mathrm{SO}_{3}+\mathrm{H}_{2} \mathrm{SO}_{4} \rightarrow 2 \mathrm{CH}_{3} \mathrm{~S}(\mathrm{O})_{2} \mathrm{OH}+\mathrm{SO}_{2} \\
& \mathrm{CH}_{3} \mathrm{SO}_{2}+\mathrm{H}_{2} \mathrm{SO}_{4} \rightarrow \mathrm{CH}_{3} \mathrm{~S}(\mathrm{O})_{2} \mathrm{OH}+\mathrm{HOSO}_{2}
\end{aligned}
$$

$\mathrm{CH}_{3} \mathrm{~S}(\mathrm{O}) \mathrm{CH}_{3}+\mathrm{CH}_{3} \mathrm{~S}(\mathrm{O}) \mathrm{OH} \rightarrow \mathrm{CH}_{3} \mathrm{SCH}_{3}+\mathrm{CH}_{3} \mathrm{~S}(\mathrm{O})_{2} \mathrm{OH}(3)$

Reactions 1 and 2 were used to determine the $\Delta \mathrm{H}_{\mathrm{f}}{ }^{\circ}$ for MSA at $298.15 \mathrm{~K}$ and $1 \mathrm{~atm}$. Reaction 3 was used to MSIA at the same conditions. The choice of these reactions is due to the fact that they involve reactants and products whose thermochemistry is relatively well established. The enthalpies of formation of $\mathrm{CH}_{3} \mathrm{~S}(\mathrm{O}) \mathrm{CH}_{3}(\mathrm{DMSO}), \mathrm{CH}_{3} \mathrm{SCH}_{3}$ (DMS), $\mathrm{SO}_{3}, \mathrm{SO}_{2}, \mathrm{H}_{2} \mathrm{SO}_{4}$ and $\mathrm{HOSO}_{2}$ used in this work were $-150.5,{ }^{24}-37.5,{ }^{25}-395.77,{ }^{26}-296.84,{ }^{26}-735.13,{ }^{26}$ and $-373 \mathrm{~kJ} \mathrm{~mol}^{-1}{ }^{-27}$ respectively. The $\Delta \mathrm{H}_{\mathrm{f}}{ }^{\circ}$ for $\mathrm{CH}_{3} \mathrm{SO}_{2}$ is the one obtained in a previous high level theoretical study, $-218.4 \mathrm{~kJ} \mathrm{~mol}^{-1}{ }^{28,29}$ The values for the calculated reaction enthalpies are collected in the first column of Table 2. The average value obtained for MSA is $-566.2 \mathrm{~kJ} \mathrm{~mol}^{-1}$. This value can be compared with the one reported by Guthrie and Gallant, ${ }^{15}$ using calorimetric measurements, which are $562.41 \pm 9.58 \mathrm{~kJ} \mathrm{~mol}^{-1}$. The agreement is very good.

Reaction 3 was used to determine the $\Delta \mathrm{H}_{\mathrm{f}}{ }^{\circ}$ of the MSIA1 and MSIA2 conformers, considering the value for $\Delta \mathrm{H}_{\mathrm{f}}{ }^{\circ}$ of MSA determined in this work. The values obtained were also listed in Table 2. Considering the atmospheric proportion of MSIA1 and MSIA2 of 70 and $30 \%$ determined above, the $\Delta \mathrm{H}_{\mathrm{f}}^{\circ}$ of MSIA was calculated as a weighted average. The value obtained is $-337.2 \mathrm{~kJ} \mathrm{~mol}^{-1}$. 
Table 2. Reaction enthalpies $\left(\Delta \mathrm{H}_{\mathrm{r}}^{\circ}\right)$ for the three reactions studied and enthalpies of formation $\left(\Delta \mathrm{H}_{\mathrm{f}}^{\circ}\right)$ determined for MSA and for the two MSIA conformers in $\mathrm{kJ} \mathrm{mol}^{-1}$

\begin{tabular}{lcc}
\hline & $\Delta \mathrm{H}_{\mathrm{r}}{ }^{\circ}(\mathrm{kJ} \mathrm{mol})^{1}$ & $\Delta \mathrm{H}_{\mathrm{f}}{ }^{\circ}$ calculated $(\mathrm{kJ} \mathrm{mol})^{1}$ \\
\hline Reaction 1 & -142.22 & MSA: -563.39 \\
Reaction 2 & 11.49 & MSA: -572.81 \\
Reaction 3 & -115.38 & MSIA1: -339.72 \\
Reaction 3 & -117.60 & MSIA2: -337.50 \\
\hline
\end{tabular}

Concerning the theoretical calculations of Wang and Zhang, ${ }^{16}$ the values obtained for $\Delta \mathrm{H}_{\mathrm{f}}^{\circ}$ of MSA and MSIA are -563 and $-331 \mathrm{~kJ} \mathrm{~mol}^{-1}$, respectively. It is a reasonable agreement. However, we can emphasize that the present calculations are conducted in a better level of theory and results represent the first theoretical determination of this quantity considering the existence of two MSIA conformers.

\section{Conclusions}

The structural and spectroscopic properties of methanesulfinic (MSIA) and methanesulfonic (MSA) acids were theoretically investigated. Extensive theoretical conformation analysis was conducted in order to identify the minimum energy for these two species. The geometry optimizations were conducted at the UMP $2 / \mathrm{cc}-\mathrm{pV}(\mathrm{T}+\mathrm{d}) \mathrm{Z}$ level of calculation, and single points calculations were added to reach the $\operatorname{CCSD}(\mathrm{T}) / \mathrm{CBS}$ level of accuracy. There is only one stable MSA conformer and two MSIA conformers. Using these results and thermochemical data from the literature, the enthalpy of formation was determined for these two important atmospheric species, working with a set of isodesmic reactions. For the methanesulfinic acid, the average value for the enthalpy of formation was determined to be $-337.2 \mathrm{~kJ} \mathrm{~mol}^{-1}$, taking into account the proportion of the two conformers in the equilibrium. For methanesulfonic acid, the enthalpy of formation was obtained as being $-566.2 \mathrm{~kJ} \mathrm{~mol}^{-1}$. These values are in good agreement with the available previous experimental and theoretical results. Since the present calculations were conducted at a high level of theory, and it is the only study where the two MSIA conformers were considered, these results are the most confident thermochemical data presented up to date.

\section{Acknowledgments}

The authors thank Conselho Nacional de Desenvolvimento Científico e Tecnológico (CNPq, Process 473761/2008-4) and Fundação de Amparo à Pesquisa do Estado de Minas Gerais (FAPEMIG, Process CEX APQ0558-5.02/07) for support and research grants.

\section{References}

1. Pham, M.; Müller, J.-F.; Brasseur, G. P.; Granier, C.; Mégie, G.; J. Geophys. Res. 1995, 100, 26061.

2. Coakley, J. A.; Bernstein, R. L.; Durkee, P. A.; Science 1987, 237, 1020.

3. Charlson, R. J.; Lovelock, J. E.; Andreae, M. O.; Warren, S. G.; Nature 1987, 326, 655.

4. Bates, T. S.; Charlson, R. J.; Gammon, R. H.; Nature 1987, 329, 319.

5. Librando, V.; Tringali, G.; Hjorth, J.; Coluccia, S.; Environ. Poll. 2004, 127, 403.

6. von Glasow, R.; Crutzen, P. J.; Atmos. Chem. Phys. 2004, 4, 589.

7. Resende, S. M.; De Almeida, W. B.; J. Phys. Chem. A 1997, 101, 9738.

8. Hatakeyama, S.; Okuda, M.; Akimoto, H.; Geophys. Res. Lett. 1982, 9, 583.

9. Arsene, C.; Barnes, I.; Becker, K. H.; Schneider, W. F.; Wallington, T. J.; Mihalopoulos, N.; Patroescu-Klotz, I. V.; Env. Sci. Tech. 2002, 36, 5155.

10. Yin, F.; Grosjean, D.; Seinfeld, J. H.; J. Atmos. Chem. 1990, 11,309 .

11. Sorensen, S.; Falbe-Hansen, H.; Mangoni, M.; Hjorth, J.; Jensen, N. R.; J. Atmos. Chem. 1996, 24, 299.

12. Urbanski, S. P.; Stickel, R. E.; Wine, P. H.; J. Phys. Chem. A 1998, 102, 10522.

13. Tian, Y.; Tian, Z. M.; Wei, W. M.; He, T. J.; Chen, D. M.; Liu, F. C.; Chem. Phys. 2007, 335, 133.

14. Gonzalez-Garcia, N.; Gonzalez-Lafont, A.; Lluch, J. M.; J. Phys. Chem. A 2007, 111, 7825.

15. Guthrie, J. P.; Gallant, R. T.; Can. J. Chem. 2000, 78, 1295.

16. Wang, L. M.; Zhang, J. S.; J. Mol. Struct.-Theochem 2002, 581, 129.

17. Wilson, A. K.; Dunning, T. H.; J. Phys. Chem. A 2004, 108, 3129.

18. Frisch, M. J.; Trucks, G. W.; Schlegel, H. B.; Scuseria, G. E.; Robb, M. A.; Cheeseman, J. R.; Montgomery, J. A., Jr.; Vreven, T.; Kudin, K. N.; Burant, J. C.; Millam, J. M.; Iyengar, S. S.; Tomasi, J.; Barone, V.; Mennucci, B.; Cossi, M.; Scalmani, G.; Rega, N.; Petersson, G. A.; Nakatsuji, H.; Hada, M.; Ehara, M.; Toyota, K.; Fukuda, R.; Hasegawa, J.; Ishida, M.; Nakajima, T.; Honda, Y.; Kitao, O.; Nakai, H.; Klene, M.; Li, X.; Knox, J. E.; Hratchian, H. P.; Cross, J. B.; Bakken, V.; Adamo, C.; Jaramillo, J.; Gomperts, R.; Stratmann, R. E.; Yazyev, O.; Austin, A. J.; Cammi, R.; Pomelli, C.; Ochterski, J.; Ayala, P. Y.; Morokuma, K.; Voth, G. A.; Salvador, P.; Dannenberg, J. J.; Zakrzewski, V. G.; Dapprich, S.; Daniels, A. D.; Strain, M. C.; Farkas, O.; Malick, D. K.; Rabuck, A. D.; Raghavachari, K.; Foresman, J. B.; Ortiz, J. V.; Cui, Q.; Baboul, A. G.; Clifford, S.; Cioslowski, J.; Stefanov, B. B.; Liu, G.; Liashenko, A.; Komaromi, I.; 
Martin, R. L.; Fox, D. J.; Al-Laham, M. A.; Nanayakkara, A.; Challacombe, M.; Gill, P. M. W.; Johnson, B.; Pople, J. A.; Gaussian 03, Revision D.01, Gaussian Inc., Wallingford, CT, 2004.

19. Dunning, T. H.; Peterson, K. A.; Wilson, A. K.; J. Chem. Phys. 2001, 114, 9244.

20. Curtiss, L. A.; Raghavachari, K.; Trucks, G. W.; Pople, J. A.; J. Chem. Phys. 1991, 94, 7221.

21. Nobes, R. H.; Bouma, W. J.; Radom, L.; Chem. Phys. Lett. 1982, 89, 497.

22. Givan, A.; Loewenschuss, A.; Nielsen, C. J.; J. Mol. Struct. 2005, 748, 77 .

23. Durig, J. R.; Zhou, L.; Schwartz, T.; Gounev, T.; J. Raman Spectrosc. 2000, 31, 193 .
24. Masuda, N.; Nagano, Y.; Sakiyama, M.; J. Chem. Thermod. 1994, 26, 971.

25. Voronkov, M. G.; Klyuchnikov, V. A.; Kolabin, S. N.; Shvets, G. N.; Varusin, P. I.; Deryagina, E. N.; Korchevn, N. A.; Tsvetnitskaya, S. I.; Dokl. Phys. Chem. 1989, 307, 650.

26. Chase Jr., M. W.; NIST-JANAF Thermochemical Tables, $4^{\text {th }}$ ed., J. Phys. Chem. Ref. Data, 1998, Monograph 9, 1-1951.

27. Somnitz, H.; Phys. Chem. Chem. Phys. 2004, 6, 3844.

28. Resende, S. M.; Ornellas, F. R.; Chem. Phys. Lett. 2003, 367, 489.

29. Resende, S. M.; Ornellas, F. R.; J. Braz. Chem. Soc. 2002, 13, 565.

Submitted: August 27, 2010 Published online: February 8, 2011 